\title{
Early age at menarche and its associated factors in school girls (age, 10 to 12 years) in Bangladesh: a cross-section survey in Rajshahi District, Bangladesh
}

Jannatul Maowa Malitha', Md. Ariful Islam', Saima Islam², Abu Sayed Md. Al Mamun', Suman Chakrabarty ${ }^{3}$ and Md. Golam Hossain ${ }^{1 *}$

\begin{abstract}
Background: Early onset of menarche is one of the most important factors for breast cancer and other associated health hazards. The aim of this study was to investigate the early age at menarche and its associated factors in school girls (age, 10-12 years) in Rajshahi District, Bangladesh.

Methods: Data was collected from Rajshahi District, Bangladesh, using multistage random sampling. Independent sample $t$ test and binary logistic regression model were used in this study. A total number of 386 school girls aged 10-12 years were considered as a sample for this study.

Results: This study revealed that more than $48 \%$ girls already attained menarche within the age of 12 years, among them $25.6 \%, 41.0 \%$, and $58.3 \%$ girls experienced menarche at the age of 10,11 , and 12 years, respectively. It was observed that the menarcheal girls were significantly taller $(p<0.01)$ and heavier $(p<0.01)$ than non-menarcheal girls. The menarcheal girls' mothers were heavier $(p<0.01)$, shorter $(p<0.01)$, had more BMI $(p<0.01)$, reached menarche $(p<0.05)$ earlier than non-menarcheal girls' mothers. Menarcheal girls had less number of siblings $(p<0.01)$ and lower order of birth $(p<0.05)$ than non-menarcheal girls. After controlling the effect of other factors, multiple logistic regression model demonstrated that obese girls were more likely to attain menarche than under- $[\mathrm{AOR}=0.279, \mathrm{Cl} 95 \% 0.075-0.986 ; p<0.05]$ and normal $[\mathrm{AOR}=0.248, \mathrm{Cl} 95 \%$ 0.082-0.755; $p<$ 0.05] weight girls. Urban school girls had more chance to get menarche than rural school girls at same age $(\mathrm{AOR}=0.012,95 \% \mathrm{Cl} 0.003-0.047 ; p<0.01)$.
\end{abstract}

Conclusions: Therefore, modern lifestyle changes may have the important factors for early age at menarche of the studied girls in Bangladesh.

Keywords: Age at menarche, School girls, Rajshahi District, Independent sample $t$ test, Logistic regression model

\footnotetext{
* Correspondence: hossain95@yahoo.com

'Department of Statistics, University of Rajshahi, Rajshahi 6205, Bangladesh

Full list of author information is available at the end of the article
}

(c) The Author(s). 2020 Open Access This article is licensed under a Creative Commons Attribution 4.0 International License, which permits use, sharing, adaptation, distribution and reproduction in any medium or format, as long as you give appropriate credit to the original author(s) and the source, provide a link to the Creative Commons licence, and indicate if changes were made. The images or other third party material in this article are included in the article's Creative Commons licence, unless indicated otherwise in a credit line to the material. If material is not included in the article's Creative Commons licence and your intended use is not permitted by statutory regulation or exceeds the permitted use, you will need to obtain permission directly from the copyright holder. To view a copy of this licence, visit http://creativecommons.org/licenses/by/4.0/ The Creative Commons Public Domain Dedication waiver (http://creativecommons.org/publicdomain/zero/1.0/) applies to the data made available in this article, unless otherwise stated in a credit line to the data. 


\section{Background}

The first menstrual bleeding is referred to as menarche, and age at menarche is the most significant period of a girl's life, and it is a part of complex process of physical and emotional development of a girl. Menarche is the most commonly remembered milestone of puberty for most women, and it is often considered the signals of fertility from both social and medical perspectives. Girls experience menarche at different ages but usually it occurs between the ages of 10 and 16 years, and the mean age at menarche varies significantly by geographical region, race, ethnicity, and other characteristic factors, especially nutritional factors [1, 2]. Recently, it was found that estradiol is an important factor for the occurrence of kisspeptin expression in GnRH (gonadotropin releasing hormone) neurons in the prepubertal period, and its gradual development provides a GnRH neuron amplification mechanism that is used to facilitate the emergence of pulsatile gonadotropin secretion necessary for puberty onset. It was also found that a single nucleotide polymorphism of $L I N 28 B$ on chromosome 6 was associated with earlier menarche [3]. Besides genetics, menarche is also influenced by hereditary [4], early biological maturation, and many socioeconomic and environmental factors [5]. It has been reported that early onset of menarche is one of the important indicators for getting some diseases such as breast cancer [6] and ischemic heart disease [7]. Recently, Won et al. found that early menarche was significantly associated with hypertension, diabetes, and metabolic syndrome of Korean women [8]. Fida et al. reported that women who had early menarche $(<12$ years old $)$ were more likely to get asthma than their counterparts who got menarche ( $\geq 12$ years old) [9]. It has been also found that delayed menarche is associated with some complications such as irregular menstrual cycles, low peak bone mass [10], and type I diabetes [11]. The nature of the relationship between menarcheal age and anthropometric measures may be important in understanding the significance of the effects of menarcheal age on disease in later life of women. Numerous researchers have shown that age at menarche is associated with height, weight, body mass index, and socio-economic and demographic factors $[12,13]$. There is a huge number of studies available with menarcheal age of adolescent girls worldwide. With respect to Bangladeshi populations, researchers have studied menstruation among Bangladeshi females, and they have tried to find the relationship between age at menarche and nutritional status, post-menarcheal growth, marriage, anthropometric measures, and sociodemographic factors $[14,15]$. Most of the studies in Bangladesh have been done with adult women. The educational attainment of a population is an important indicator of the society's stock of human capital and level of socioeconomic development. The literacy rate especially women education level and family wealth quintile have been increasing during the last two decades in Bangladesh [16]. The mean age of menarche has declined over the last century all over the world especially in developed and developing countries. It is important to study on puberty status (age at menarche) among school going girls (age 10-12 years), and determine the risk factors for early age at menarche, in order to ensure corrective measures can be undertaken. Some studies with other population already have found that recently some girls got menarche at age 10 years $[1,17]$. In this study, we considered school girls with age of 10-12 years for investigating their menstrual characteristics and to determine factors of early onset of menarche.

The aim of the study was to investigate the early age at menarche and its associated factors among school going girls aged 10-12 years in Rajshahi District, Bangladesh.

\section{Materials and methods}

\section{Materials}

The target area for this study was Rajshahi District, which is situated in the north-western part of the Bangladesh. The total area of the district is $2425.37 \mathrm{~km}^{2}$ and the population is 2,699,688 according to BBS (2011, adjusted on 16 March 2012) including the urban and rural population of the district. The population of this study was school girls with age at 10 to 12 years in Rajshahi District, Bangladesh. The subjects were all of Bangladeshi birth. The present study was a cross-sectional study. The data was collected from the field survey. It was conducted from March to July 2017.

\section{Methods}

\section{Sample size determination}

The following formula was used to calculate the required sample size for this study:

$n=\frac{z^{2} p(1-p)}{d^{2}}$, where $n=$ the number of samples, $z=1.96$ for $95 \%$ confidence interval, $p=0.5$, and finally $5 \%$ margin of error $(d=0.05)$ were considered. The above formula provided that 385 was the required sample size for the present study. However, initially, we considered 400 (4\% extra) samples for assuming non-response rate. Unfortunately, 14 selected girls were not interested to provide their information. Finally, 386 samples were considered in this study and their information was collected by the principal author.

\section{Sample selection procedures}

Multistage random sampling technique was utilized for selecting sample covering all the population from three upazilas (the third largest administrative division in Bangladesh) of Rajshahi district. There were 9 upazilas of Rajshahi District. In the first stage, 3 upazilas were selected from 9 upazilas by simple random sampling. In the second stage, 3 schools were selected from each upazila by random sampling. Total selected schools were 3 $\times 3=9$. In the third stage, 400 girls were selected by 
random sampling with proportion allocation technique. Principal author described the objective of the present study with selected girls. Written consent of each selected girl and school authorities' permission had been taken. A standard questionnaire was distributed to 386 girls for getting their socio-economic and demographic information.

\section{Outcome variable}

The outcome variable of this study was puberty status (age at menarche) of school girls aged 10-12 years. Initially girls were asked, "Did you have experience menstruation?" If yes, then asked, when (age in year) did you attain menarche? The information was double checked over phone from the girl's mother. The sample was classified into two classes according to their menstrual status such as (i) menarcheal girls (code, 1), (ii) nonmenarcheal girls (code, 0 ).

\section{Independent variables}

Parents' socio-economic and demographic factors and girls' anthropometric measures were considered as independent variables in this study. The categorical variables were type of residence (rural and urban), mode of delivery (normal and caesarian), parent's education level (uneducated, primary education, secondary education, and higher education), father's occupation (service, business, and farmer), mother's occupation (housewife and service), family income ( $\leq 20,000 \mathrm{Tk}$ and $>20,000 \mathrm{Tk}$ per month), girl's body mass index (BMI) (underweight $(\leq 5$ th percentiles of BMI), normal weight (5th to 85th percentiles of BMI), overweight (85th to 95th percentiles of BMI), and obese ( $\geq 95$ th percentiles of BMI). The quantitative variables were number of siblings, order of birth, girl's weight (in $\mathrm{kg}$ ) and height (in $\mathrm{cm}$ ), mother's weight (in $\mathrm{kg}$ ), height (in $\mathrm{cm}$ ), BMI $\left(\mathrm{kg} / \mathrm{m}^{2}\right)$, and their age at menarche. Most of the independent variables had been selected on the basis of the previous studies $[10,12,18]$.

\section{Data collection procedure}

All information of selected girls was gathered from respective school authorities. Girl's current age was calculated by the difference between survey and birth date (considering nearest integer age category) and classified into one of the age categories. Digital scales and a portable stadiometer were used to measure their weight and height respectively. Measurement of individuals was taken without shoes and wearing light clothes using the techniques of Martin and Saller [19]. Height and weight were measured to the nearest $1 \mathrm{~cm}$ and $0.1 \mathrm{~kg}$, respectively, and body mass index was calculated using the formula, $B M I=$ weight $(\mathrm{kg}) /$ height $(\mathrm{m})^{2}$. Mothers' height and weight were also measured by the same procedures as applied for their girls.

\section{Statistical analysis}

Frequency distribution was used to determine the prevalence of age at menarche of girls with age 10 to 12 years. Independent sample $t$ test was utilized in this study to find the difference between menarcheal and nonmenarcheal girls for quantitative variables. Both simple and multiple binary logistic regression models were used to determine the effect of categorical independent factors on age at menarche among school girls (age 10 to 12 years). Standard error (SE) was used to detect the multicollinearity problem among independent factors for multiple logistic regression model, if the magnitude of the SE lies between 0.001 and 0.5 , it is judged that there is no evidence of multicollinearity [20]. Finally, the Nagelkerke $\mathrm{R}^{2}$ value and Hosmer and Lemeshow test were utilized in this study to find the goodness of fit of multiple models. All statistical significance was accepted at $p<0.05$. Statistical analyses were performed by using the SPSS software (IBM version-22).

\section{Results}

A total number of 386 school girls aged 10-12 years were considered as sample for this study, among them 43 (11.1\%), 139 (36.0\%), and 204 (52.8\%) girls were 10, 11 , and 12 years old respectively. The number of girls in the youngest group was smaller compared to the other two groups. This happened because most of the girls in the youngest group felt shy to talk about their menarcheal status, and they refused to answer.

\section{Prevalence of age at menarche among school girls aged 10-12 years}

Among the selected girls, 187 (48.45\%) already reached menarche, and 199 (51.55\%) girls did not get menarche. The percentage of menarcheal girls was $25 \%, 41.0 \%$, and $58.3 \%$ by their age 10, 11, and 12 respectively (Fig. 1).

\section{Proportions of menarcheal and non-menarcheal school girls by their parents socio-demographic factors and students' body size}

The proportion of menarcheal and non-menarcheal girls by their nutritional status and parents' socio-economic and students' BMI categories is presented in Table 1 . The proportion of menarcheal girls in urban area (0.726) was significantly $(p<0.01)$ higher than rural $(0.144)$. It was found that the proportion of menarcheal girls of higher educated parents was more than that of primary $(p<0.01)$ and secondary $(p<0.01)$ educated parents' girls. The higher proportion of menarcheal girls was born by cesarean system than girls who were born by normal process $(p<0.01)$. The proportion of service holder fathers' menarcheal girls was more than that of businessman $(p<0.01)$ and farmers' $(p<0.01)$ girls. The proportion of menarcheal girls of service holder mothers 


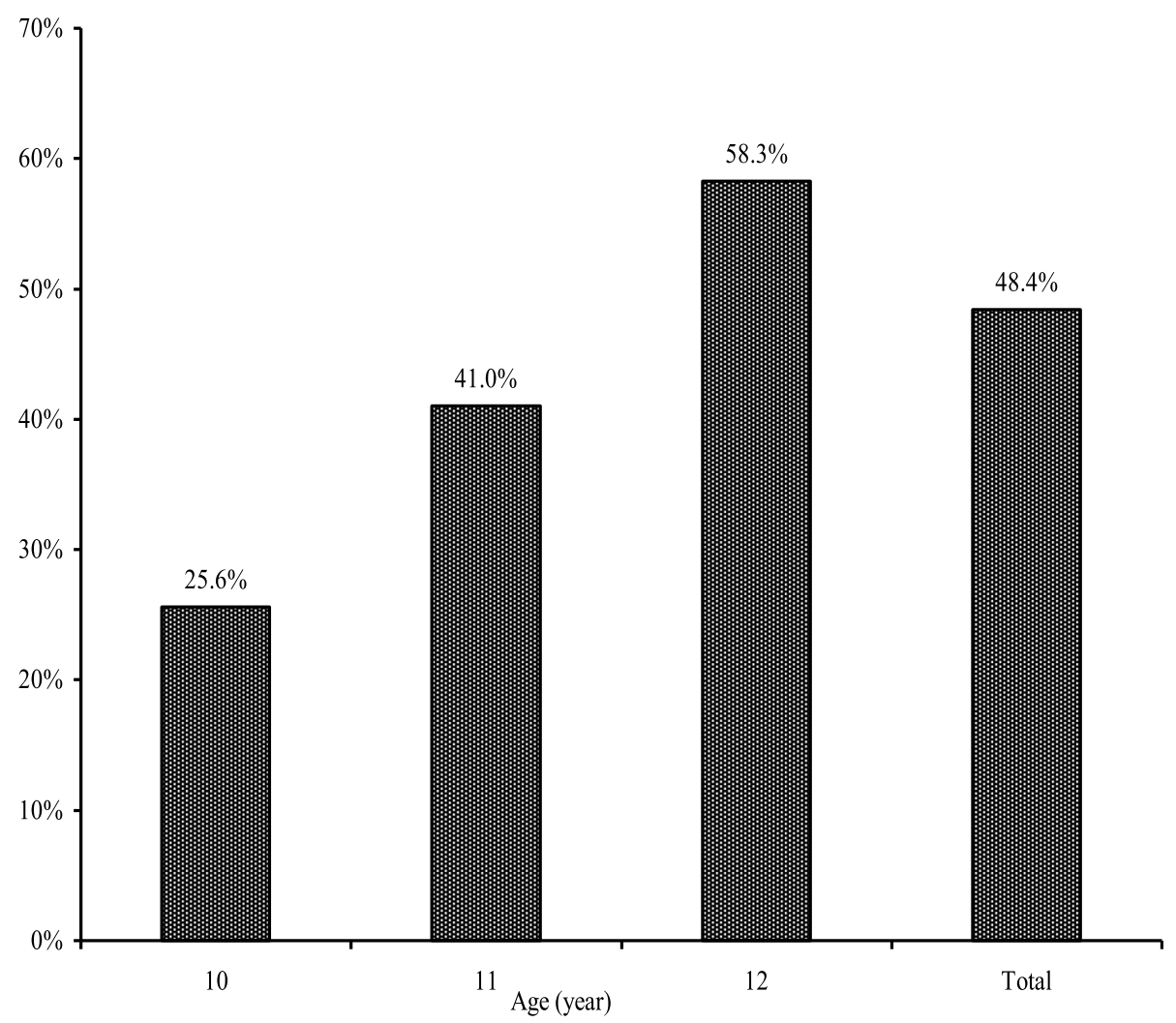

Fig. 1 Prevalence of age at menarche among school girls in Rajshahi district

was significantly $(p<0.01)$ higher than that of housewife mothers. It was observed that significantly $(p<0.01)$ more number of girls who lived in rich family reached menarche than that of comparatively poor family. It was noted that the proportion of menarcheal girls showed increasing tendency with increase in their body size, and obese girls reached menarche significantly higher than that of underweight $(p<0.01)$ and normal $(p<0.01)$ girls (Table 1).

\section{Mean difference in anthropometric and demographic variables between menarcheal and non-menarcheal girls}

The mean weight of menarcheal girls $(44.49 \pm 9.61 \mathrm{~kg})$ was significantly higher than that of non-menarcheal girls $(35.46 \pm 6.93 \mathrm{~kg})(p<0.01)$. Also, the mean height of menarcheal girls $(146.14 \pm 10.16 \mathrm{~cm})$ was significantly $(p<0.01)$ higher than non-menarcheal girls $(143.63 \pm$ $7.96 \mathrm{~cm})$. The number of siblings of non-menarcheal girls was significantly more than that of menarcheal girls $(p<0.01)$. It was found that the order of birth of nonmenarcheal girls was significantly higher than that of menarcheal girls $(p<0.05)$. The mean weight and BMI of menarcheal girl's mother were significantly higher than non-menarcheal girls' mothers $(p<0.01)$, but the height of menarcheal girls' mothers was lower than nonmenarcheal girls' mothers $(p<0.01)$. It was also found that mean age at menarche of non-menarcheal girl's mother was significantly higher than that of menarcheal girl's mother $(p<0.01)$ (Table 2$)$.

\section{Effects of parent's socio-economic and girl's nutritional status on their early age at menarche}

The results of simple and multiple logistic regression models were interpreted by odds ratio (OR) and adjusted odds ratio (AOR) respectively. Simple logistic regression model demonstrated that obese school girls aged 10-12 years were more likely to reach menarche than that of girls having normal weight $[\mathrm{OR}=0.122$, 95\% CI 0.0 .045 $0.325 ; p<0.01]$ and underweight $[\mathrm{OR}=0.069,95 \% \mathrm{CI}$ $0.023-0.210 ; p<0.01]$. It was noted that service holder mothers' girls had 0.342 times higher chance to reach menarche than that of housewife mothers' girls $[\mathrm{OR}=0.342$, 95\% CI 0.195-0.597; $p<0.01$ ]. Service holder [OR = 5.480, 95\% CI 2.902-10.350; $p<0.01]$ and businessman $[\mathrm{OR}=1.953,95 \%$ CI 1.005-3.797; $p<0.01]$ fathers' girls were more likely to attain menarche than that of farmers' girls. Higher educated mothers' girls were more likely to reach menarche 0.308 [OR $=0.308,95 \%$ CI $0.162-0.586 ; p$ $<0.01]$ and 0.382 times $[\mathrm{OR}=0.382,95 \%$ CI $0.228-0.639$; $p<0.01]$ higher than primary and secondary educated mothers' girls respectively. Higher educated fathers' girls had a more chance to get menarche than that of primary 
Table 1 The proportions of menarcheal and non-menarcheal girls by their anthropometric and demographic variables

\begin{tabular}{|c|c|c|c|c|c|c|}
\hline \multirow[t]{4}{*}{ Variables } & \multicolumn{6}{|c|}{ Did you attain menarche? } \\
\hline & \multicolumn{3}{|l|}{ Yes } & \multicolumn{3}{|l|}{ No } \\
\hline & \multirow[t]{2}{*}{ Proportion } & \multicolumn{2}{|l|}{$95 \% \mathrm{Cl}$} & \multirow[t]{2}{*}{ Proportion } & \multicolumn{2}{|l|}{$95 \% \mathrm{Cl}$} \\
\hline & & Lower & Upper & & Lower & Upper \\
\hline \multicolumn{7}{|l|}{ Type of residence } \\
\hline Rural & 0.144 & 0.093 & 0.208 & 0.856 & 0.792 & 0.902 \\
\hline Urban** & 0.726 & 0.663 & 0.783 & 0.274 & 0.217 & 0.337 \\
\hline \multicolumn{7}{|l|}{ Mode of delivery } \\
\hline Normal & 0.438 & 0.373 & 0.504 & 0.562 & 0.496 & 0.627 \\
\hline Cesarean* & 0.556 & 0.473 & 0.636 & 0.444 & 0.364 & 0.527 \\
\hline \multicolumn{7}{|c|}{ Father's education level } \\
\hline Uneducated & 0.412 & 0.184 & 0.671 & 0.588 & 0.329 & 0.816 \\
\hline Primary & 0.283 & 0.168 & 0.423 & 0.717 & 0.577 & 0.832 \\
\hline Secondary & 0.286 & 0.179 & 0.413 & 0.714 & 0.587 & 0.821 \\
\hline Higher** & 0.581 & 0.518 & 0.643 & 0.419 & 0.357 & 0.482 \\
\hline \multicolumn{7}{|c|}{ Mother's education level } \\
\hline Uneducated & 0.357 & 0.128 & 0.649 & 0.643 & 0.351 & 0.872 \\
\hline Primary & 0.302 & 0.183 & 0.443 & 0.698 & 0.557 & 0.817 \\
\hline Secondary & 0.349 & 0.249 & 0.459 & 0.651 & 0.541 & 0.751 \\
\hline Higher** & 0.584 & 0.518 & 0.648 & 0.416 & 0.352 & 0.482 \\
\hline \multicolumn{7}{|l|}{ Father's occupation } \\
\hline Service ${ }^{* *}$ & 0.637 & 0.564 & 0.705 & 0.363 & 0.295 & 0.436 \\
\hline Business & 0.385 & 0.301 & 0.474 & 0.615 & 0.526 & 0.699 \\
\hline Farmer & 0.242 & 0.154 & 0.364 & 0.758 & 0.636 & 0.855 \\
\hline \multicolumn{7}{|l|}{ Mother's occupation } \\
\hline Housewife & 0.438 & 0.383 & 0.495 & 0.562 & 0.505 & 0.617 \\
\hline Service** & 0.696 & 0.573 & 0.801 & 0.304 & 0.199 & 0.427 \\
\hline \multicolumn{7}{|c|}{ Monthly family income } \\
\hline$\leq 20,000$ (Taka) & 0.340 & 0.273 & 0.413 & 0.660 & 0.587 & 0.727 \\
\hline$>20,000(\text { Taka })^{* *}$ & 0.621 & 0.550 & 0.689 & 0.379 & 0.311 & 0.450 \\
\hline \multicolumn{7}{|l|}{ Girls' BMI category } \\
\hline Underweight & 0.286 & 0.173 & 0.422 & 0.714 & 0.578 & 0.827 \\
\hline Normal & 0.414 & 0.350 & 0.479 & 0.586 & 0.521 & 0.650 \\
\hline Overweight & 0.746 & 0.616 & 0.850 & 0.254 & 0.150 & 0.384 \\
\hline Obese ${ }^{* *}$ & 0.853 & 0.689 & 0.950 & 0.147 & 0.050 & 0.311 \\
\hline
\end{tabular}

${ }^{*} 5 \%$ and ${ }^{* *} 1 \%$ level of significantly higher

[OR $=0.285,95 \%$ CI $0.149-0.544 ; p<0.01]$ and secondary [OR $=0.288$, 95\% CI 0.158-0.526; $p<0.01]$ educated fathers' girls. It was found that girls who were born by cesarean had 0.623 times higher chance to attain menarche than that of girls born by vaginal system $[\mathrm{OR}=0.623$, 95\% CI $0.413-0.939 ; p<0.01]$. It was also observed that urban girls were more likely to get menarche than that of rural girls $[\mathrm{OR}=0.063,95 \%$ CI $0.037-0.108 ; p<0.01]$ (Table 3). After controlling for potential confounders, multiple logistic regression model showed that obese school girls aged 10 to 12 years were $0.279(0.075-0.986)$ and $0.248(0.082-0.755)$ times higher $(p<0.05)$ chance to attain menarche than under and normal weight girls respectively. Also, urban school girls was more likely to get menarche than rural school girls $[\mathrm{AOR}=0.012,95 \% \mathrm{CI}$ 0.003-0.047; $p<0.01$ ]. Negelkerke $\mathrm{R}^{2}$ demonstrated that our selected model is able to explain the variation of outcome variable by $50.20 \%$, and Hosmer and Lemeshow test showed that [Chi-square value $=3.005 ; p>0.05$ ] selected model was good fitted for the data (Table 3 ). 
Table 2 Mean difference in anthropometric and demographic variables between menarcheal and non-menarcheal girls

\begin{tabular}{|c|c|c|c|c|c|c|}
\hline \multirow[t]{2}{*}{ Variable } & \multirow{2}{*}{$\begin{array}{l}\text { Did you } \\
\text { attain menarche? }(M)\end{array}$} & \multirow[t]{2}{*}{ Mean } & \multirow[t]{2}{*}{ SD } & \multicolumn{2}{|c|}{$\underline{95 \% \mathrm{Cl} \text { for Mean }}$} & \multirow{2}{*}{$\begin{array}{l}p \\
\text { value }\end{array}$} \\
\hline & & & & Lower & Upper & \\
\hline \multirow[t]{2}{*}{ Girl's weight (kg) } & No (199) & 35.46 & 6.93 & 34.49 & 36.43 & 0.001 \\
\hline & Yes (187) & 44.49 & 9.61 & 43.11 & 45.88 & \\
\hline \multirow[t]{2}{*}{ Girl's height (cm) } & No (199) & 143.63 & 7.96 & 142.52 & 144.74 & 0.008 \\
\hline & Yes (187) & 146.14 & 10.16 & 144.67 & 147.60 & \\
\hline \multirow[t]{2}{*}{ Number of siblings } & No (199) & 2.43 & 0.91 & 2.30 & 2.55 & 0.003 \\
\hline & Yes (187) & 2.16 & 0.82 & 2.04 & 2.28 & \\
\hline \multirow[t]{2}{*}{ Order of birth } & No (199) & 1.87 & 0.96 & 1.74 & 2.00 & 0.013 \\
\hline & Yes (187) & 1.65 & 0.79 & 1.53 & 1.76 & \\
\hline \multirow[t]{2}{*}{ Mother's weight (kg) } & No (199) & 57.40 & 8.91 & 55.85 & 58.96 & 0.001 \\
\hline & Yes (187) & 62.51 & 8.23 & 61.33 & 63.70 & \\
\hline \multirow[t]{2}{*}{ Mother's height $(\mathrm{cm})$} & No (199) & 155.37 & 4.91 & 154.50 & 156.24 & 0.001 \\
\hline & Yes (187) & 150.98 & 7.62 & 149.88 & 152.08 & \\
\hline \multirow[t]{2}{*}{ Mother's BMI $\left(\mathrm{kg} / \mathrm{m}^{2}\right)$} & No (199) & 23.80 & 3.85 & 23.11 & 24.48 & 0.001 \\
\hline & Yes (187) & 27.52 & 3.82 & 26.97 & 28.07 & \\
\hline \multirow[t]{2}{*}{ Mother's age at menarche (year) } & No (199) & 13.19 & 1.14 & 12.84 & 13.54 & 0.017 \\
\hline & Yes (187) & 12.70 & 1.39 & 12.50 & 12.90 & \\
\hline
\end{tabular}

\section{Discussion}

\section{Prevalence of age at menarche}

Adolescent school girls (age, 10-12 years) were considered in this study to investigate their menarcheal status and factor influencing early age at menarche in Rajshahi District, Bangladesh. It was found that around 50\% adolescent school girls aged 10-12 years reached menarche, among them $58.3 \%$ and $41.0 \%$ girls got menarche at age 12 and 11 years respectively, while only $25.6 \%$ school girls experienced menarche at their very early age (10 years). However, the frequency of the girls at age 10 years was smaller compared to the other groups. Due to lack of knowledge on menstruation or due to shyness and embarrassment, the frequency of early age at (10 year) menarche was very low in this study.

In other Bangladeshi studies, it was found that $35.7 \%$ urban school students got menarche at the age of 12 years [21]. The prevalence of menarcheal girls among Bangladeshi rural adolescent aged 10-17 was 37.8\% [22]. In Pakistan, it was found that $0.8 \%$ girls attainted menarche at age 8 years; however, $46 \%$ girls got menarche in 10-14 year age group [23]. There are few studies available with age at menarche of adolescent girls in Bangladesh [21] and Bangladeshi female adults [15-22]. Study on prevalence of menarche and identify factors which were related to early onset of menarche among Bangladeshi adolescent school girls aged 10-12 years to compare menarcheal girls with non-menarcheal girls was poorly documented. Hossain et al. reported that the mean and median age at menarche of Bangladeshi university students (Birth-year cohorts from 1979 to 1986) were $13.12 \pm 1.16$ years and 13.17 years respectively [22] Meng et al. reported that the age at menarche has declined worldwide [24]. Other studies reported that the average age of age at menarche among Pakistani girls was 11.73 years [20], Indian girls was 12.4 years [25], and the mean age at menarche of Nigerian school girls was 12 years [26].

\section{Menarcheal age and anthropometric measures}

This study observed that taller and obese girls reached menarche in their early life than underweight or normal weight girls because body size parameters, such as weight or BMI and height, are strongly correlated with the age at menarche. Frisch and Revelle proposed a critical body weight and weight gain for the onset of menarche [27, 28]. Higher subcutaneous fat levels and BMI at prepubertal ages (5-9years) are associated with increased likelihood of early (< 11 years) menarche [29]. Same result had been found in a South Korean study; Kim et al. found that the menarcheal girls aged 10-14 were taller and heavier than non-menarcheal girls among South Korean adolescent girls [30]. Also, they found that menarcheal girls had more BMI than nonmenarcheal ones. Our results were also supported by an African study; Engidaw and Gebremariam found that Somalian adolescent refugee girls living in eastern Somali refugee camps who did not start menstruating were less likely to be thin/wasted compared to those who did [31]. For Okasha et al. who found that in female students at the University of Glasgow, age at menarche was positively associated with adult height and negatively 
Table 3 Effect of parent's socio-economic and girl's nutritional status on age at menarche of school girls (age, 10-12 years)

\begin{tabular}{|c|c|c|}
\hline Variables & OR $(95 \% \mathrm{Cl}$ of $\mathrm{OR})$ & AOR ( $95 \% \mathrm{Cl}$ of $\mathrm{AOR})$ \\
\hline \multicolumn{3}{|l|}{ Girls' BMI category } \\
\hline Underweight & $0.069(0.023-0.210)^{* *}$ & $0.279(0.075-0.986)^{*}$ \\
\hline Normal weight & $0.122(0.045-0.325)^{* *}$ & $0.248(0.082-0.755)^{*}$ \\
\hline Over weight & $0.506(0.166-1.543)$ & $0.594(0.169-2.085)$ \\
\hline Obesity $^{\mathbf{R}}$ & & 1.00 \\
\hline \multicolumn{3}{|l|}{ Mother's occupation } \\
\hline Housewife & $0.342(0.195-0.597)^{* *}$ & $0.753(0.320-1.773)$ \\
\hline Survice $^{\mathbf{R}}$ & & 1.00 \\
\hline \multicolumn{3}{|l|}{ Father's occupation } \\
\hline Service & $5.480(2.902-10.350)^{* *}$ & $1.396(0.402-4.843)$ \\
\hline Business & $1.953(1.005-3.797)^{* *}$ & $1.281(0.457-3.595)$ \\
\hline \multicolumn{3}{|l|}{ Farmer $^{\mathbf{R}}$} \\
\hline \multicolumn{3}{|c|}{ Monthly family income } \\
\hline$\leq 20,000$ (Taka) & $0.315(0.208-0.477)^{* *}$ & $1.499(0.893-2.680)$ \\
\hline \multicolumn{3}{|l|}{$>20,000(\text { Taka })^{\mathbf{R}}$} \\
\hline \multicolumn{3}{|c|}{ Mother's education level } \\
\hline Uneducated & $0.396(0.129-1.219)$ & $0.872(0.116-6.569)$ \\
\hline Primary & $0.308(0.162-0.586)^{* *}$ & $0.829(0.232-2.964)$ \\
\hline Secondary & $0.382(0.228-0.639)^{* *}$ & $0.889(0.360-2.197)$ \\
\hline \multicolumn{3}{|l|}{ Higher $^{\mathbf{R}}$} \\
\hline \multicolumn{3}{|c|}{ Father's education level } \\
\hline Uneducated & $0.505(0.186-1.369)$ & $4.698(1.844-7.200)$ \\
\hline Primary & $0.285(0.149-0.544)^{* *}$ & $3.125(1.632-5.451)$ \\
\hline Secondary & $0.288(0.158-0.526)^{* *}$ & $2.030(0.560-7.362)$ \\
\hline \multicolumn{3}{|l|}{ Higher $^{\mathbf{R}}$} \\
\hline \multicolumn{3}{|l|}{ Mode of birth } \\
\hline Normal & $0.623(0.413-0.939)^{*}$ & $1.142(0.645-2.023)$ \\
\hline \multicolumn{3}{|l|}{ Cesarean $^{\mathbf{R}}$} \\
\hline \multicolumn{3}{|l|}{ Type of Residence } \\
\hline Rural & $0.063(0.037-0.108)^{* *}$ & $0.012(0.003-0.047)^{* *}$ \\
\hline \multicolumn{3}{|l|}{ Urban $^{\mathbf{R}}$} \\
\hline \multicolumn{3}{|l|}{ Model summary } \\
\hline Negelkerke $\mathrm{R}^{2}$-value & & 0.502 \\
\hline Goodness of fit & $\begin{array}{l}\text { Hosmer and } \\
\text { Lemeshow test }\end{array}$ & $\begin{array}{l}\text { Chi-square } \\
\text { value }=3.005^{n}\end{array}$ \\
\hline
\end{tabular}

** $1 \%$ and $* 5 \%$ level of significance

$R$ reference case, $C l$ confidence interval, $O R$ odds ratio, $A O R$ adjusted odds ratio

associated with weight [32] and BMI; in Bangladeshi studies, Hossain et al. reported that age at menarche of Bangladeshi female students was negatively associated with adult BMI but positively associated with adult height [15]. These results were also supported by the findings of Chowdhury et al. who found that the age at menarche of Bangladeshi females was negatively associated with BMI and positively with height [22], and Ersoy et al. who reported an inverse relationship between age at menarche and post-menarcheal weight and BMI of Turkish female students [33].

\section{Menarcheal age and family socio-demographic factors}

Logistic regression model demonstrated that school girls had less number of siblings experienced menarche earlier than their counterparts. Szwed et al. demonstrated that the girls from large families (four and more children) were the latest to cross the pubertal threshold on average at the age of 13.54 years [18]. It was observed that school girls aged 10-12 years who were living in urban areas and girls in urban living with rich family got menarche earlier compare to rural girls and they eat more nutritious food than rural girls. Consequently, they become more fatty; as a result, they got menarche earlier than rural girls. These results are in agreement with others finding [34]. The present study demonstrated that parents' educational level and occupation have a significant influence on their daughter's age at menarche. Also, we found that mothers' BMI was an important factor of their daughter's early menarche. Evidence for hereditary influences on the age at menarche comes from studies that show a trend for maternal age at menarche to predict daughter's age at menarche [35]. In fact, approximately half of the phenotypic variation among girls from developed countries in the timing of menarche is due to genetic factors [4].

To the author's knowledge, there have been no comparable studies on this in Bangladesh to date. However, in a similar study conducted on female university students in Portugal, Padez found no association between a girl's age at menarche and her parent's educational level and occupation [36]. It seems that parental education and employment does not have any direct effect on menarcheal age and might exert its effect indirectly through influencing family lifestyle [37]. The present study found that females from rural locations had a later age at menarche than those who spent their adolescence in urban areas. Identical results have been found in Portugal [36] and Spain [38]. It may be difficult to make conclusions based on multiple studies from different parts of the world and perhaps more local, regional studies should be conducted. This study only investigated the age at menarche and it is associated with some factors of the adolescent school girls. Other important factors that may be directly implicated in menstrual problems are birth weight [39], childhood living conditions [40], food habits in childhood [34], physical activity, lifestyle factors and nutrition [41], history of smoking, dietary habits, psychosocial stress, and dieting [42, 43]. 


\section{Conclusion}

In this study, we investigated the menarcheal status among school girls aged 10-12 years in Rajshahi District, Bangladesh. The prevalence of age at menarche among school girls was $48.4 \%$, and a remarkable number of girls $(25.6 \%)$ got menarche at the age of 10 . It was observed that taller and heavier girls got menarche earlier than their counterparts. The mean height and BMI of menarcheal girls' mother were significantly higher than nonmenarcheal girls' mothers. Also, it was noted that comparatively heavier mothers' girls got menarche earlier than their counterpart. High maternal BMI is a risk factor for daughter's early onset of menarche. There was a positive association between mother's age at menarche and their daughters' age at menarche. Overnourished and urban girls were more likely to get menarche than undernourished and rural girls. Age at menarche of school girls was influenced by their parents' sociodemographic and their anthropometric factors. Parent's educational level and occupation have a significant influence on their daughter's age at menarche. It was noted that, school girls had less number of siblings who experienced menarche earlier than their counterparts.

\section{Abbreviations}

BMI: Body mass index; SE: Standard error; OR: Odds ratio; AOR: Adjusted odds ratio; $\mathrm{Cl}$ : Confidence interval; $\mathrm{P}: P$ value

\section{Acknowledgements}

Authors wish to acknowledge the school girl students who were willing to participate in this study voluntarily. The authors also would like to express their heartfelt thanks to the school authorities for giving permission to contact their female students.

\section{Authors' contributions}

JMM and GH created the concept; MAI, SI, and GH created the design of the study; JMM and ASMAM performed the statistical analysis; JMM, MAI, SI, and $\mathrm{GH}$ drafted the manuscript. GH, ASMAM, and SC made revision of the manuscript. All authors read and approved the final manuscript

\section{Funding}

The authors have no support or funding to report.

\section{Availability of data and materials}

The study was based on the primary data. The data will be provided when necessary.

\section{Ethics approval and consent to participate}

Authors followed all the rules and regulations of the ethical committee. Since no biological factors were considered in the present study, ethical approval was not required. Written consent was taken from each participant.

\section{Consent for publication}

Not applicable for this study.

\section{Competing interests}

The authors declare that they have no competing interests.

\section{Author details}

'Department of Statistics, University of Rajshahi, Rajshahi 6205, Bangladesh. ${ }^{2}$ Australian Research Centre for Population Oral Health (ARCPOH), The University of Adelaide, Adelaide, South Australia 5005, Australia. ${ }^{3}$ Department of Anthropology, Mrinalini Datta Mahavidyapith, Vidyapith Road, Birati, Kolkata 700 051, India.
Received: 24 November 2019 Accepted: 11 March 2020

Published online: 23 March 2020

\section{References}

1. Kamarulzaman SA, Mohamed PN, Ridzuan PM. Age at menarche and menstrual pattern among adolescences girls in Selangor. J Nat Ayurvedic Med. 2019;3(2):000175. https://doi.org/10.23880/jonam-16000175.

2. Zeglen M, Marini E, Cabras S, Lukasz K, Das R, Chakraborty A. The relationship among the age at menarche, anthropometric characteristics, and socio-economic factors in Bengali girls from Kolkata, India. Am J Human Biol. 2019:e23380. https://doi.org/10.1002/ajhb.23380.

3. Karapanou O, Papadimitriou A. Determinants of menarche. Reprod Biol Endocrino. 2010;8:115. https://doi.org/10.1186/1477-7827-8-115.

4. Towne B, Czerwinski SA, Demerath EW, Blangero J, Roche AF, Siervogel RM. Heritability of age at menarche in girls from the Fels Longitudinal Study. Am J Phys Anthropol. 2005;128:210-9. https://doi.org/10.1002/ajpa.20106.

5. Huma K, Komal K, Maheen F, Mahrukh F, Mahum I, Myera S, Mazia S, Pashmal Y, Ain QU, Rubab S. Age of menarche in relation to socioeconomic status BMI, physical activity and stress among high school girls. Proceedings (Shaikh Zayed Postgraduate Medical Institute). 2015;29:35-40.

6. Bodicoat DH, Schoemaker MJ, Jones ME, Griffin J, Ashworth A, Swerdlow AJ. Timing of pubertal stages and breast cancer risk; the Breakthrough Generations study. Breast Cancer Res. 2014;16(1):R18. https://doi.org/10. 1186/bcr3613.

7. Cooper GS, Ephross SA, Weinberg CR, Baird DD, Whelan EA, Sandler DP. Menstrual and reproductive risk factors for ischemic heart disease. Epidemiology. 1999;10(3):255-9.

8. Won JC, Hong JW, Noh JH, Kim DJ. Association between age at menarche and risk factors for cardiovascular diseases in Korean women. Medicine. 2016;95(18):e3580. https://doi.org/10.1097/MD.0000000000003580.

9. Fida NG, Williams MA, Enquobahrie DA. Association of age at menarche and menstrual characteristics with adult onset asthma among reproductive age women. Reprod Syst Sexual Disord. 2014;11(3):111. https://doi.org/10.4172/ 2161-038X.1000111.

10. Anai T, Miyazaki F, Tomiyasu T, Matsuo T. Risk of irregular menstrual cycles and low peak bone mass during early adulthood associated with age at menarche. Pediatr Int. 2001:43(5):483-8.

11. Danielson KK, Palta M, Allen C, D'Alessio DJ. The association of increased total glycosylated hemoglobin levels with delayed age at menarche in young women with type1 diabetes. J Clin Endocrinol Metabol. 2005;90(12):6466-71.

12. Ameade EP, Garti HA. Age at menarche and factors that influence it: a study among female university students in Tamale, Northern Ghana. PLoS ONE. 2016;11(5):e0155310. https://doi.org/10.1371/journal.pone.0155310.

13. Klis K, Majcher A, Paluchowska M, Wronka I. Determinants of BMI category changes during middle childhood and adolescence in girls. Folia Med Cracoviensia. 2016;56(2):25-36.

14. Haque SE, Rahman M, Itsuko K, Mutahara M, Sakisaka K. The effect of a school-based educational intervention on menstrual health: an intervention study among adolescent girls in Bangladesh. Br Med J. 2013;4(7):e004607. https://doi.org/10.1136/bmjopen-2013-004607.

15. Hossain MG, Islam S, Aik S, Zaman TK, Lestrel PE. Age at menarche of university students in Bangladeshi: secular trends and association with adult anthropometric measures and socio-demographic factors. J Biosoc Sci. 2010;42(5):677-87.

16. NIPORT. Bangladesh Demographic and Health Survey 2014. National Institute of Population of Population Research and Training. ICF International, Dhaka, Bangladesh and Calverton, MD, USA: Mitra and Associates; 2014

17. Bhattarai S, Subedi S, Acharya SR. Factors associated with early menarche among adolescents girls: a study from Nepal. SM J Commun Med. 2018;4(1):1028.

18. Szwed A, John A, Czapla Z, Kosinska M. Influence of socioeconomic factors on age at menarche of Polish girls. Anthropologischer Anzeiger. 2013;70(4): 455-70. https://doi.org/10.1127/0003-5548/2013/0338.

19. Martin, R. \& Saller, K. Lehrbuch der anthropologie. 1957. Gustav Fischer Verlag, Stuttgart.

20. Chan YH. Biostatistics 202: logistic regression analysis. Singapore Med J. 2004;45(4):149-53.

21. Islam MS, Hussain MA, Islam S, Mahumud RA, Biswas T, Islam SMS. Age at menarche and its socioeconomic determinants among female students in an urban area in Bangladesh. Sexual Reprod Healthcare. 2017;12:88-92. https://doi.org/10.1016/j.srhc.2017.03.008. 
22. Chowdhury S, Shahabuddin AK, Seal AJ, Talukder KK, Hassan Q, Begum RA, Rahman Q, Tomkins A, Costello A, Talukder MQ. Nutritional status and age at menarche in rural area of Bangladesh. Annals Human Biol. 2000;27(3):249-56.

23. Ahmed SM, Waheed MA, Ahmad F, Danish SH. Factors contributing to early menarche in school girls. J Pakistan Med Assoc. 2016;66(5):629-33.

24. Meng X, Li S, Duan W, Sun Y, Jia C. Secular trend of age at menarche in Chinese adolescents born from 1973 to 2004. Pediatrics. 2017;140(2): e20170085. https://doi.org/10.1542/peds.2017-0085.

25. Khadgawat R, Marwaha RK, Mehan N, Surana V, Dabas A, Sreenivas V, Gaine MA, Gupta N. Age of onset of puberty in apparently healthy school girls from Northern India. Indian Pediatr. 2016;53(5):383-7.

26. Irewole-Ojo FO, Senbanjo IO, Oduwole AO, Njokanma OF. Age of pubertal events among school girls in Lagos, Nigeria. J Pediatr Endocrinol Metabol. 2018;31(3):313-21.

27. Frisch RE, Revelle R. Height and weight at menarche and a hypothesis of critical body weights and adolescent events. Science. 1970;169:377-9. https://doi.org/10.1126/science.169.3943.397.

28. Frisch RE, Revelle R. Height and weight at menarche and a hypothesis of menarche. Arch Dis Child. 1971;46:675-701. https:/doi.org/10.1136/adc.46.249.695.

29. Freedman DS, Khan LK, Serdula MK, Dietz WH, Srinivasan SR, Berenson GS. Relation to age at menarche to race, time period, and anthropometric dimensions: the Bogalusa Heart Study. Pediatrics. 2002;1 10:e43. https://doi. org/10.1542/peds.110.4.e43

30. Kim JY, Oh $1 \mathrm{H}$, Lee EY, Oh CM, Choi KS, Choe BK, Yoon TY, Shin SH, Choi JM. The relation of menarcheal age to anthropometric profiles in Korean girls. J Korean Med Sci. 2010;25(10):1405-10.

31. Engidaw MT, Gebremariam AD. Prevalence and associated factors of stunting and thinness Somalian refugee girls living in eastern Somali refugee camps, Somali regional state, Southeast Ethiopia. Conflict Health. 2019;13(17):10.1186/s13031-019-0203-3.

32. Okasha M, McCarron P, McEwen J, Smith GD. Age at menarche: secular trends and associated with adult anthropometric measures. Annals Human Biol. 2001;28(1):68-78.

33. Ersoy B, Balkan C, Gunay T, Onag A, Egemen A. Effects of different socioeconomic conditions on menarche in Turkish female students. Early Human Dev. 2004;76(2):115-25.

34. Windham GC, Bottomley C, Birner C, Fenster L. Age at menarche in relation to maternal use of tobacco, alcohol, coffee, and tea during pregnancy. Am J Epidemiol. 2004;159(9):862-71.

35. Graber JA, Brooks-Gunn J, Warren MP. The antecedents of menarcheal age: heredity, family environment, and stressful life events. Child Dev】. 1995;66: 346-59. https://doi.org/10.2307/1131582.]

36. Padez C. Social background and age at menarche in Portuguese university students: a note on the secular changes in Portugal. Am J Human Biol. 2003;15(3):415-27.

37. Tehrani FR, Mirmiran P, Gholami R, Moslehi N, Azizi F. Factors influencing menarcheal age: results from the cohort of Tehran Lipid and Glucose Study. Int J Endocrinol Metab. 2014;12(3):e16130. https://doi.org/10.5812/ijem.16130.

38. Marrodan MD, Mesa MS, Aréchiga J, Pérez-Magdaleno A. Trend in menarcheal age in Spain: rural and urban comparison during a recent period. Annals Human Biol. 2000;27(3):313-9.

39. Silva DSI, Stavola DBL, Mann V, Kuh D, Hardy R, Wadsworth ME. Prenatal factors, childhood growth trajectories and age at menarche. Int J Epidemiol. 2002:31(2):405-12.

40. Kac G, de S.C.C A, Velasquez-Melendez G. Secular trend in age at menarche for women born between 1920 and 1979 in Rio de Janeiro, Brazil. Annals Human Biol. 2000;27(4):423-8

41. Merzenich $\mathrm{H}$, Boeing $\mathrm{H}$, Wahrendorf J. Dietary fat and sports activity as determinants for age at menarche. Am J Epidemiol. 1993;138(4):217-24.

42. Balbi C, Musone R, Menditto A, Di Prisco L, Cassese E, D'Ajello M, Ambrosio D, Cardone A. Influence of menstrual factors and dietary habits on menstrual pain in adolescence age. Eur J Obstetr Gynecol Reprod Biol. 2000;91 (2):143-8.

43. Yamamoto K, Okazaki A, Sakamoto Y, Funatsu M. The relationship between premenstrual symptoms, menstrual pain, irregular menstrual cycles, and psychosocial stress among Japanese college students. J Physiol Anthropol. 2009:28(3):129-36

\section{Publisher's Note}

Springer Nature remains neutral with regard to jurisdictional claims in published maps and institutional affiliations.

\section{Ready to submit your research? Choose BMC and benefit from:}

- fast, convenient online submission

- thorough peer review by experienced researchers in your field

- rapid publication on acceptance

- support for research data, including large and complex data types

- gold Open Access which fosters wider collaboration and increased citations

- maximum visibility for your research: over $100 \mathrm{M}$ website views per year

At BMC, research is always in progress.

Learn more biomedcentral.com/submissions 